\title{
Rebalancing Growth in China: A Three-Handed Approach
}

\author{
Olivier Blanchard, Francesco Giavazzi *
}

\begin{abstract}
The present paper is an attempt to define the contours of the right macroeconomic strategy for China. In a nutshell, we believe that the package includes a decrease in saving, with a focus on private saving, an increase in the supply of services, in particular health services, and an appreciation of the RMB. This is why we refer to this strategy as a "three-handed approach": action on the fiscal and budgetary front, accompanied by currency revaluation. We start by asking how the Chinese economy got to where it is, what the strategy has been since the beginning of the reforms, and what the main characteristics of the economy are today. We then ask what is the desirable path for the future, and which are the main policy trade-offs implied by such a path. Finally, we put the various pieces together to describe what we believe is a consistent policy package.
\end{abstract}

K ey words: growth, saving, appreciation, strategy

J E L codes: E21, E61, F31

\section{Introduction}

On 21 July 2005 China began the process of rebalancing its economy. The new exchange rate rule will, over time, reduce the incentive to invest in the export sector. This is the right move for China because there are increasing signs that the economy has proceeded too far

\footnotetext{
* Olivier Blanchard, Professor of Economics, Massachussets Institute of Technology, Cambridge (Mass.) and National Bureau of Economic Research, Cambridge (Mass.), USA. Email: blanchar@ mit.edu. Francesco Giavazzi, Professor of Economics, Bocconi university, Milan, Italy and National Bureau of Economic Research, Cambridge (Mass.) and the Center of Economic Policy Research, London, UK. Email: francesco. giavazzi@unibocconi.it. This paper was prepared for the project on "China and the Global Economy 2010" of the China Economic Research and Advisory Program. We thank Edwin Lim for help and discussions, Ricardo Caballero, Ricardo Hausmann, Eswar Prasad and Francesco Sisci for comments, and He Fan and other researchers at the Institute of World Economics and Politics, Chinese Academy of Social Sciences for help with data.
} 
into manufacturing for export markets, to the point that the country's capital stock is misallocated: too much in manufacturing, too little in the domestic service industry, in particular in the provision of health services.

The government has announced that the national poll tax will be eliminated in all rural provinces and is considering reducing, in those provinces, some local taxes as well. It has also introduced free elementary education and some free basic health services for all rural households. These policies are also right, for two reasons. First, the prices of agricultural products in China follow international prices very closely; The revaluation will, therefore, be accompanied by a corresponding fall in the local currency price of foodstuffs and, as a consequence, a fall in rural incomes. Second, a substantial revaluation risks pushing the economy into a recession, or at least a significant slowdown in growth. Using fiscal policy to support domestic demand is clearly appropriate. Doing so by focusing primarily on rural provinces appears, therefore, to be the right approach both from a distribution and from a macroeconomic viewpoint.

The present paper is an attempt to define the contours of the right macroeconomic strategy for China. In a nutshell, we believe that the package includes a decrease in saving, with a focus on private saving, an increase in the supply of services, in particular health services, and an appreciation of the RMB. This is why we refer to this strategy as a "threehanded approach": action on the fiscal and budgetary front, accompanied by currency revaluation.

Before describing the optimal policy mix, we start by asking in Section II how the Chinese economy got to where it is, what the strategy has been since the beginning of the reforms, and what the main characteristics of the economy are today. In Section III we use this assessment to ask what the desirable path is for the future, and which are the main policy trade-offs implied by such a path. Finally, in Section IV we put the various pieces together to describe what we believe is a consistent policy package.

\section{The Strategy So Far}

\section{Saving and Exports}

Partly as a result of deliberate policy choices, partly by historical accident, China's economic strategy since the early 1990s has been characterized by two features: high saving and high capital accumulation, and export-led growth. ${ }^{1}$

\footnotetext{
${ }^{1}$ A more detailed characterization of China's growth, with a comparison to past rapid growth experiences, such as those of Korea and Japan, is given in Hausmann (2005).

(C)2006 The Authors

Journal compilation (C2006 Institute of World Economics and Politics, Chinese Academy of Social Sciences
} 


\section{High Saving}

China's national saving rate, 43 percent of GDP in 2003, is unusually high, no matter which group of countries China is compared to. The recent revision of China's national income statistics lowered the estimated saving rate to 40 percent of GDP (a number simply using a different GDP number on the denominator), which still remains higher than any group of comparable countries (see Table 1).

The high national saving rate reflects both high private and high public saving. The fraction of saving invested abroad has been relatively small: in the past 15 years China has always run a current account surplus, but never a very large one ( 2 percent of GDP on average since 1990). As a result of high household saving, private consumption has been relatively low: as shown in Table 2, it is now 49 percent of GDP, having lost 6 percentage points since the early 1990s. This reduction in private consumption has gone entirely into financing domestic investment, which over the same period has gained the same share of GDP, 6 percent.

\section{High Exports and High Imports}

Openness, measured by the share of trade (exports plus imports) in GDP is 60 percent today (2003). China is about as open as France and Italy, two economies deeply integrated in the European Single Market (for comparison, average trade openness is below 40 percent in Latin America.) In less than 10 years, China has nearly doubled its degree of openness by raising both exports and imports by an order of magnitude more than the increase in world trade (see Table 3). Much of this trade is related to Chinese processing of imported intermediate goods (processing trade accounts for approximately half of total Chinese

Table 1. National Saving Rate (Percent of GDP, 2003)

\begin{tabular}{l|c}
\hline China & $40.2(r)$ \\
\hline Low income countries & 20.3 \\
\hline Lower-middle income countries & 30.4 \\
\hline Middle income countries & 28.3 \\
\hline Upper-middle income countries & 23.9 \\
\hline
\end{tabular}

Source: World Bank (2004); $r$ based on revised GDP data from the 2005 National Economic Census released by the National Bureau of Statistics of China.

Table 2. Composition of Demand (Percent of GDP)

\begin{tabular}{l|c|c}
\hline & 1991 & 2003 \\
\hline Consumption & 62 & 56 \\
\hline Private & 49 & 43 \\
\hline Public & 13 & 13 \\
\hline Investment & 36 & 42 \\
\hline Exports & 16 & 31 \\
\hline Imports & 14 & 29 \\
\hline
\end{tabular}

Source: National Bureau of Statistics of China (2004). 
Table 3. Growth Rate of Exports and Imports (Percent Per Year)

\begin{tabular}{l|c|c|c}
\hline Exports & $1980 \mathrm{~s}$ & $1990 \mathrm{~s}$ & $2000-2003$ \\
\hline China & 5.7 & 12.4 & 23.1 \\
\hline World & 5.0 & 6.2 & $5.8^{\mathrm{a}}$ \\
\hline Imports & $1980 \mathrm{~s}$ & $1990 \mathrm{~s}$ & $2000-2003$ \\
\hline China & 10.2 & 15.5 & 23.5 \\
\hline World & 4.7 & 5.8 & 5.3 \\
\hline
\end{tabular}

Source: The World Bank (2004).

N ote: ${ }^{a} 2000-2002$.

trade). One of the major benefits of openness, learning-by-doing, occurs precisely in the area of processing trade.

Overall, this has clearly been a very successful strategy.

\section{Per Capita Income}

In just 15 years Chinese GDP per capita (purchasing power parity corrected) has increased from being equal to that of India to being now twice as large. Or to take another example, it has gone from 18 percent of Korean GDP to 29 percent. These are impressive achievements.

\section{Total Factor Productivity and Learning-by-doing}

Between 1990 and 2002 labor productivity growth in industry has averaged 12.5 percent per year. These productivity gains are obviously related to the high investment rate, but as shown in Hu, et al.(2003) learning-by-doing has contributed to an increase in total factor productivity (TFP). The estimates of TFP growth computed by various authors and discussed in Wang (2005) range around 3 percent per year since the beginning of the reforms (Table 4). More recently, however, as discussed in Hu and Zheng (2004), TFP

Table 4. TFP Growth, Various Estimates

\begin{tabular}{l|c|c}
\hline Author & Period & Annual TFP growth \\
\hline Mengkui Wang & $1978-1985$ & 0.5 \\
\hline & $1978-2003$ & 2.4 \\
\hline Shantong Li & $1982-1997$ & 1.4 \\
\hline Maddison & $1952-1978$ & -0.8 \\
\hline & $1978-1995$ & 2.2 \\
\hline World Bank & $1978-1995$ & 3.1 \\
\hline Jinghai Zheng & $1979-1984$ & 7.7 \\
\hline & $1985-1990$ & 2.2 \\
\hline & $1991-1995$ & 3.7 \\
\hline Baoliang Zhu & $1995-2001$ & 0.6 \\
\hline
\end{tabular}

Source: Wang (2005).

$\mathrm{N}$ ote: TFP, total factor productivity

(C)2006 The Authors

Journal compilation (C2006 Institute of World Economics and Politics, Chinese Academy of Social Sciences 
Table 5. Price Indices (Rate of Change, 2003)

\begin{tabular}{l|c}
\hline Ex-factory prices (\%) & 2.3 \\
\hline Price deflator, investment in fixed assets (\%) & 2.2 \\
\hline Price deflator, machine building industry (\%) & -3.0 \\
\hline Price deflator, building materials industry (\%) & -0.4 \\
\hline
\end{tabular}

Source: National Bureau of Statistics of China (2004).

growth appears to have slowed significantly; we shall return to this below.

\section{No Evidence of Overheating}

With respect to labor, there appears to be no general pressure on wages. With respect to capital, the evidence from prices of machinery and building materials in particular suggest, if anything, excess supply (Table 5).

\section{Imbalances}

However, along with growth, several social and economic imbalances have emerged.

\section{Uneven Growth across Provinces}

In the 1970s, per capita income in urban areas was three times its level in rural areas: controls on the price of foodstuffs and limitations to labor mobility were aimed at favoring the cities. The reforms of the 1980s brought that ratio down to 2.2. Since 1990, however, it has risen again and was back to 3.2 in 2003. The same has happened to per capita consumption in urban and rural areas (Table 6). This divergence between urban and rural households is also reflected, not surprisingly, in an increasing divergence in income per capita between provinces (last column of Table 6). The standard deviation of income per capita across provinces has increased by 72 percent between 1998 and 2003.

Growth differences across provinces have been larger than what can be explained by different characteristics, such as geography, or the endowment of human capital. In particular, the policy of awarding fiscal privileges to exporters and investors in selected areas has contributed directly to the widening of income differences. Cities that have been granted the status of "special economic zones" have grown by as much as 5 percent per

Table 6. Ratio of Per Capita Income and Consumption, Urban to Rural Households, and Top 8 to Bottom 22 Provinces

\begin{tabular}{l|c|c|c}
\hline & Income ratio: urban to rural & Consumption ratio: urban to rural & Income ratio: provinces \\
\hline 1979 & 2.6 & 2.9 & \\
\hline 1990 & 2.2 & 3.0 & \\
\hline 1998 & 2.9 & 3.4 & 2.8 \\
\hline 2003 & 3.2 & 3.6 & 3.1 \\
\hline
\end{tabular}

Source: National Bureau of Statistics of China (2004). 
year faster than the rest (Jones et al., 2003). Spillovers across provinces have also contributed to the widening of income disparities because (as shown in Brun et al., 2002) such spillovers have been positive among coastal provinces, but non-existent between coastal and inland or western regions.

\section{Uneven Growth across Skill Levels}

We estimate that the skilled--unskilled wage differential has risen from 1.3 to 2.1 in a decade. The large migration flows from rural to urban areas and from inland and western provinces to coastal provinces suggest that the countryside has been used mainly as a reservoir of labor. The high supply elasticity of unskilled labor has certainly been a factor in the rise of the skilled-unskilled differential.

How large is this elasticity? Using a survey of residents in the Hubei province, $\mathrm{Zu}$ (2002) finds that the wages of workers who have migrated to the city are twice as high as those of workers who have remained in the countryside. Part of this difference reflects differences in skills. However, even after correcting for differences in skills, the wage of a migrant worker remains higher than that of a farmer (correcting for differences in skills, the ratio falls from 2 to 1.8), suggesting that returns to skills are larger in the city, but also that migrating is costly (one of the main factors here are the legal restrictions on mobility, under the policy known as the Hukou policy). Therefore, we are far from perfect arbitrage between rural and urban jobs. The interesting question, however, is by how much a widening of the wage differential induces higher migration. The same survey indicates that a 10 percent fall in rural wages, holding wages in the city constant, raises migration flows by approximately 0.5 percent. Therefore, fluctuations in rural incomes are an important determinant of the decision to migrate, although the cost of moving prevents perfect arbitrage. As we shall discuss, this is an important fact when asking what the effects of a revaluation are, because a currency revaluation lowers incomes in the countryside.

\section{Uneven Growth across Sectors}

Not surprisingly, given the strategy and the composition of exports (in 2003, 91 percent of Chinese exports were manufactured goods), the share of manufacturing in GDP is large, quite independently of the group of countries to which China is compared (Table 7). The share of services is correspondingly low, even after the recent GDP revision, which has raised the estimated share of services in 2004 from 32 to 41 percent of GDP. This reflects a low provision of health services, with the situation getting worse in the countryside (We shall return to this below.) The reported share of retail and wholesale trade is low as well; 
Table 7. Composition of Output (Value Added, Percent of GDP, 2000)

\begin{tabular}{l|c|c|c}
\hline & Agriculture & Industry & Services \\
\hline China 1990 & 27 & 42 & 31 \\
\hline China 2004 & 15 & 53 & 32 \\
\hline China 2004 $(r)$ & 13 & 46 & 41 \\
\hline Other countries (2003) & \multicolumn{3}{|c}{} \\
\hline Low income countries & 24 & 27 & 49 \\
\hline $\begin{array}{l}\text { Lower-middle income } \\
\text { countries }\end{array}$ & 11 & 37 & 52 \\
\hline $\begin{array}{l}\text { Upper-middle income } \\
\text { countries }\end{array}$ & 6 & 35 & 59 \\
\hline World & 4 & 28 & 68 \\
\hline
\end{tabular}

Source: World Bank (2004) and National Bureau of Statistics of China (2004).

N ote: $r$ based on revised GDP data from the 2005 National Economic Census released by the National Bureau of Statistics.

we are skeptical that this is indeed the case, but we have no data to confirm or challenge it. ${ }^{2}$

\section{Safety Nets Have Substantially Weakened}

The high saving rate reflects (as we show below) a high level of individual risk, related to health costs, retirement and the financing of education. The decrease in social insurance has left individuals with the need to self-insure: an expensive and very imperfect solution. The decrease in safety nets has become particularly relevant in the area of health, and the transition to a fee-based health-care and education system (more on this below) has compounded the effects of widening income inequality.

\section{A Misallocation of Investment}

The saving glut, combined with a bank-centered financial system and privileged access to funds by state firms, has resulted in misallocation of investment. The fall in measured TFP growth should probably not be interpreted as a decrease in true technological progress, but rather as a reflection of capital misallocation, leading to a marginal productivity of capital close to zero or even being negative in parts of manufacturing ${ }^{3}$. However, capital

\footnotetext{
${ }^{2}$ The low share of retail and wholesale trade in GDP compared with countries at a similar stage of development might reflect, to some extent, the undervalued exchange rate (more on this below). An undervalued exchange rate is likely to translate to a low price of non-traded goods, such as services, relative to traded goods (manufacturing). Therefore, the low share of retail and wholesale trade in GDP might reflect a low price rather than a low quantity of trade services. For the same reason, manufacturing might be overstated, and so might investment volume.

${ }^{3} \mathrm{Hu}$ and Zheng (2004) estimate that TFP growth has fallen from 3.7 percent in 1991-1995 to 0.6 percent during 1996-2001.
} 
productivity is probably still high for investment in social capital (e.g. health and education), especially in rural areas. Therefore, it is hard to say whether China is investing too much, but it is certainly misallocating at least some of its investment.

\section{Growing Macroeconomic Imbalances}

High saving and export-led growth do not imply trade surpluses. Investment can be equal to saving, and imports equal to exports. However, recently, saving has been running ahead of investment; equivalently exports have been running ahead of imports. The trade surplus is widening: US\$30bn in 2004, and might be running at a yearly rate as high as US\$100bn in 2005.

This description of the strategy China has followed so far with its successes and drawbacks suggests several directions for reform to which we now turn.

\section{Directions of Reform}

Large policy swings would be unwise. Notwithstanding the imbalances that have emerged, China's growth story is an extraordinary success, and one should be careful before meddling with success. Corrections of the strategy pursued so far should come more in the form of inflexion than of drastic change. We see three main directions for reform:

First, improve the ability of individuals to insure against risk. At this stage, Chinese individuals are exposed to high levels of retirement risk, health expenditure risk, and even education risk (the probability that a child is bright and requires an expensive education).

Second, reduce or reallocate investment. Investment appears to be too high in manufacturing, too low in services, especially public services. This suggests in particular higher public investment in health and education, especially aimed at rural provinces where the need is more acute.

Third, allow the RMB to appreciate to reduce the trade surplus (by implication, allow for a decline in saving relative to investment).

Each of these three directions is desirable on its own. The question is how best to combine them. A dramatic decrease in saving, by itself, would create overheating. A large appreciation of the RMB would create a recession in the export sector, and perhaps in the economy as a whole.

In some dimensions, the three directions fit well together. The combination of a decrease in saving and an appreciation of the RMB can, in principle, allow a decrease in the trade surplus while maintaining internal balance.

In other dimensions, they might conflict. Too large a decrease in private saving, as a 
result of the provision of insurance, might lead to a required large appreciation of the RMB to prevent overheating, reducing the export sector too much, and curtailing the process of learning by doing. Too large an appreciation of the RMB might increase the inequality between rural and other provinces.

With this in mind, we proceed in two steps. First, we consider the motivations and the effects of each reform, discussing what it would imply for China's macroeconomic imbalances if it were adopted in isolation. Next we ask how the three reforms can best be combined.

\section{Private Saving}

A saving rate of 43 percent is very high. Especially so when one realizes that, in an economy with overlapping generations, the aggregate saving rate is the net result of saving by the young, and dissaving by the old. This implies that the saving rate of the young must be even higher than 43 percent. How much higher? The answer depends roughly on the growth rate and the average length of an individual's life. With a growth rate of 8-10 percent per year and a half-life of 30 years, the saving of the young in China dwarfs the dissaving of the old. This implies that the saving rate of the young is higher than 43 percent, but not much higher.

From a macroeconomic viewpoint, is a 43 percent saving rate "too high"? A useful benchmark is the "golden rule". In the standard neoclassical growth model, the golden rule saving rate, the saving rate that maximizes steady state consumption, is equal to the share of capital in GDP; by that standard, 43 percent is probably too high. However, China has certainly not reached its steady state and this can justify a higher saving rate in the transition.

How much of the saving rate can be explained by life cycle considerations and how much by other considerations $?^{4}$ It is useful here to start with the breakdown of saving between households, enterprises and the government. Table 8, from Kuijs (2005), provides this breakdown for China and a few other countries. Enterprise savings accounts for almost half of China's saving rate, but the outlier in Table 8 is clearly households' saving.

Table 8. Sectoral Saving (Percent of GDP)

\begin{tabular}{l|c|c|c|c|c}
\hline & China & China & Japan & Korea & Mexico \\
\hline & 2001 & 2003 & 2001 & 2001 & 2001 \\
\hline Households & 16.0 & 16.6 & 8.2 & 4.5 & 8.0 \\
\hline Enterprises & 15.0 & 18.9 & 19.4 & 14.8 & 10.6 \\
\hline Government & 7.5 & 7.0 & -2.2 & 11.7 & 2.2 \\
\hline National saving & 38.5 & 42.5 & 25.5 & 31.0 & 20.8 \\
\hline
\end{tabular}

Source: Kuijs (2005).

${ }^{4}$ These issues are also explored by Chamon and Prasad (2005) 
Why is household saving so high? Modigliani and Cao (2004) conclude that it is largely consistent with the life cycle model (which emphasizes saving for retirement), once one takes into account the high growth rate and the one-child policy in China. High growth increases the saving of the young relative to the dissaving of the old, leading to a higher net saving rate. And the one-child policy, Modigliani and Cao argue, can account for most of the rest: a child is often an effective substitute for life cycle saving. Consequently, when strict birth control measures came into effect in the 1970s (the one-child policy) the accumulation of life cycle (tangible) assets gained in importance as a substitute for children and saving increased. Although life cycle saving is surely very relevant, there is plenty of evidence suggesting that at least part of the high saving rate reflects "precautionary" saving, the result of several distortions that force Chinese individuals to self-insure through asset accumulation: ${ }^{5}$

(1) With the decline of state-owned enterprises, the public retirement system has largely broken down (triggering reform projects, not yet implemented (see Diamond, 2004). Much of the risk of retirement, in particular the risk related to the expected length of life, is now borne by individuals. ${ }^{6}$

(2) Beginning in the early 1990s, the provision of health-care services and of education has increasingly been based on a system of fees (Table 9). Rural households appear to bear a larger share of the cost of health services than urban households (Table 10), possibly because enterprises in the city provide workers with some form of health insurance. The hypothesis that the risks born by individuals are particularly severe in the countryside is indeed consistent with the evolution of the saving rate in urban and rural areas (Table 11).

Table 9. Who Pays for Health Care and Education?

\begin{tabular}{l|c|c|c}
\hline & Health expenditures & $\begin{array}{c}\text { Out of pocket } \\
\text { percent of health spending }(\%)\end{array}$ & $\begin{array}{c}\text { School fees as percent of spending on } \\
\text { education (\%) }\end{array}$ \\
\hline 1965 & 4.7 & 16 & NA \\
\hline 1980 & 10.9 & 18 & NA \\
\hline 1991 & 37.7 & 50 & 2.3 \\
\hline 2001 & 101.7 & 61 & $12.5^{\text {a }}$ \\
\hline
\end{tabular}

Source: Kanbur and Zhang (2003).

N otes: ${ }^{a}$ 1998; Health expenditures: Recurrent health expenditures, yuan per capita, constant prices. NA not available.

\footnotetext{
${ }^{5}$ In a poll cited by Qu (2005), Chinese individuals gave the following key motivations for saving: kids' education (35 percent), retirement (32 percent), medical care (10 percent), home purchases $(7$ percent $)$ and children's wedding expenditures ( 6 percent).

${ }^{6}$ The point here is that not only do people save for retirement, but they save a lot more than they could because they cannot insure against risks associated with uncertainty about life expectancy.

(C)2006 The Authors

Journal compilation (C2006 Institute of World Economics and Politics, Chinese Academy of Social Sciences
} 
Table 10. Allocation of Health-care Costs in 1998 (Percent of Total Cost)

\begin{tabular}{l|c|c}
\hline & Cities & Countryside \\
\hline Paid by the state & 16.0 & 1.2 \\
\hline Labor related & 22.9 & 0.5 \\
\hline Semi-labor related & 5.8 & 0.2 \\
\hline Insurance & 3.3 & 1.4 \\
\hline Cooperative & 4.2 & 6.6 \\
\hline Self-paid & 44.1 & 87.4 \\
\hline Other & 3.7 & 2.7 \\
\hline
\end{tabular}

Source: Kanbur and Zhang (2003)

Table 11. Household Saving Rates in Urban and Rural Areas (Percent of Disposable Income)

\begin{tabular}{l|c|c}
\hline & Urban households & Rural households \\
\hline 1993 & 18.1 & 16.5 \\
\hline 2003 & 23.1 & 25.9 \\
\hline
\end{tabular}

Source: Calculated by Institute of World Economics and Politics researcher Yongfu Cao based on data from China Statistical Yearbook, National Bureau of Statistics, various years.

Table 12. Access to Social Benefits of Temporary and Permanent Urban Residents: Five Major Cities, 2000 (Percent of All Individuals in the Group)

\begin{tabular}{l|c|c}
\hline & Migrants & Local residents \\
\hline Health insurance & 12.4 & 67.7 \\
\hline Pension program & 10.2 & 74.4 \\
\hline Unemployment benefits & 0.8 & 33.3 \\
\hline Workplace injury insurance & 14.3 & 25.3 \\
\hline Maternity leave & 31.0 & 71.1 \\
\hline
\end{tabular}

Source: Gao et al.(2002).

Safety nets are particularly weak from migrant workers who have moved from rural to urban areas and live with temporary permits (17.7 percent of the urban population according to the 2000 Census (Bian, et al., 2004). Table 12 shows that their access to social insurance is much more limited than that of urban permanent residents.

Other factors appear to contribute to the high private saving rate, also having to do with poor financial markets.

Saving for housing: A mortgage market exists and is rapidly expanding, but remains small. One obstacle is the poor definition of property rights; for example, banks can seize a property if the borrower defaults, but are then limited in their ability to sell it.

Saving to start firms: When the growth rate is 10 percent there is a good probability of running into a good business idea. If that happens, the only way to transform the idea into 
an investment is through one's own funds. Banks lack a credit culture and bank officers are not used to taking risks. Their first concern is likely to be that, in case the idea does not work and the company defaults, they might be accused of having been bribed.

Providing retirement and health-care insurance is clearly desirable. In both cases, selfinsurance is an expensive and very imperfect solution to the presence of individual risk. Any measure that allows risks to be pooled across the population will increase welfare. A similar argument holds for the development of a mortgage market, or for lending less on collateral and more on projects.

Insurance can in part be provided by the market. For this to happen, what is needed most is a set of reforms of the legal system. For instance, in the case of mortgages, foreclosure needs to be made easier, otherwise banks will not lend. In the area of health services, private insurance can go some way towards pooling and diversifying risks, but improved access to health services, especially in the countryside, can hardly come entirely from the private sector.

All such measures, however, have one important macroeconomic implication. They will decrease the private saving rate and equivalently increase consumption. Other things equal, this might lead to overheating, or/and a decrease in capital accumulation. This implication must be kept in mind when thinking about the overall strategy below.

\section{Health Services, Taxes and Defic its}

Among the growth imbalances we listed earlier is the unusually small share of services, among them health services. The evidence is that, in the 1990s, health services have not increased in proportion to income per capita, and that the shortfall has been particularly pronounced in rural provinces. Indexes of health personnel and of hospital beds per capita show an absolute decline in the 1990s in the countryside (Table 13). Infant mortality in the countryside has also deteriorated relative to cities; the ratio, which stood at 1.5 in 1980, has increased to 1.7 in 1990, and 2.1 in 1995 (Kanbur and Zhang, 2003).

\section{Table 13. Health Care in the Cities and in the Countryside}

\begin{tabular}{c|c|c|c|c}
\hline & $\begin{array}{c}\text { Percent change in hospital beds per 1000 } \\
\text { people }\end{array}$ & \multicolumn{2}{c}{$\begin{array}{c}\text { Percent change in health-care personnel per } 1000 \\
\text { people }\end{array}$} \\
\hline & Countryside & Cities & Countryside & Cities \\
\hline $1952-1978$ & +1.662 & +220 & +72 & +176 \\
\hline $1978-1990$ & -2 & +24 & +16 & +22 \\
\hline $1990-1998$ & -23 & +5 & -9 & 0 \\
\hline $1998-2003$ & NA & NA & NA & NA \\
\hline
\end{tabular}

Source: National Bureau of Statistics of China (2000) and Kanbur and Zhang (2003).

N ote: NA, not available. 
There are likely three factors behind inadequate health services:

We focused on the first earlier: the lack of health insurance leads people both to self insure through saving, the effect we focused on, but also to buy less health care.

The second is income distribution. With the shift to a fee-based system, health care has become too expensive for many to afford (this is conceptually different from the lack of insurance). In a recent survey, 34 percent of urban respondents and 44 percent of rural respondents said they did not seek health care when ill because they could not afford it. As we have seen, this problem is particularly acute in rural areas and among migrant workers in urban areas.

Moreover, with the privatization of the township and village enterprises and an increased focus on profit rather than social insurance, much of the health-care infrastructure has not been maintained. The supply of health care is inadequate, especially in the countryside.

This suggests that reforms aimed at expanding the health service sector must focus both on demand and supply. On the demand side, we already discussed the introduction of a health insurance system. (The experience of the Vietnam health insurance program, described in World Bank (2001) and studied by Pradhan and Wagstaff (2005), suggests that such a system will improve health and allow people to save less and consume more.) Distribution considerations suggest that health provision should have a redistributive component. On the supply side, more public spending on health, from building new hospitals and clinics, to increasing the incentives to become doctors and nurses in the countryside, is also needed.

We freely admit to not knowing enough about health care in general, and about health care in China in particular, to make more specific recommendations. We also realize that some of the arguments are relevant for other publicly provided services, such as education; again we leave a discussion of spending on education to people more competent than us. However, we want to discuss the fiscal aspects of financing such expenditures, which are clearly of macroeconomic relevance. Take health care. Should increased spending on health provision by the state be financed through debt or through taxes? There are three relevant considerations here.

The first is based on standard principles of public finance. If spending is going to benefit people in the future, it makes sense to finance it through debt rather than through taxes; in this way the stream of taxes (needed to pay the interest on the debt later on) and the stream of benefits can be better aligned. This is the principle underlying the so called "golden rule" of public finance, which implies financing consumption expenditures through taxes, and investment expenditures through debt (this holds even if the investment expenditures have a low financial return, so long as the social return is high enough). These issues have been discussed in the context of the reform of the Growth and Stability Pact 
in Europe (Blanchard and Giavazzi, 2004).

The second is based on the need to achieve internal balance. We can think of fiscal policy, and the choice of taxes versus debt, as trying to avoid overheating and maintain macroeconomic balance. A very relevant example here is the program of electrification of the countryside that China embarked on after the Asian crisis. Electrification, just like health care today, was needed. At the same time, aggregate demand was lower, because of the large depreciations in many Asian countries, which China decided not to match. Therefore, financing electrification through deficits was the appropriate policy. The situation might be different this time. We argued earlier that the provision of health insurance might lead to a decrease in private saving, an increase in consumption. If this is the case, the argument for further decreasing saving through public dissaving is weak. What might be called for is a smaller rather than a larger deficit. However, an appreciation of the RMB might require an increase in demand and, therefore, a larger deficit. This uncertainty suggests that no hard decision should be made in advance, and that the government should stand ready to finance these expenditures mostly through taxes or mostly through debt depending on the circumstances.

The third argument is based on debt dynamics. When, as in the case of China today, the growth rate is much higher than the interest rate the Chinese Government has to pay on its debt, many of the standard worries associated with debt dynamics disappear. If the growth rate were to remain permanently higher than the interest rate, a government could decrease taxes and never have to increase them again: the ratio of debt to GDP would remain positive, but would not explode. If, as is likely, the growth rate eventually becomes smaller than the interest rate, the relevant implication is that larger deficits today will lead only to a small increase in debt over time, and to a low debt burden in the long run. In other words, larger deficits today might require only a modest eventual increase in taxes in the future. ${ }^{7}$ In other words, if deficits are justified on macroeconomic grounds, China should not hesitate to use them.

\section{The RMB Appreciation}

On 22 July 2005 China stopped pegging its currency to the US dollar. In the new regime, a managed float, the RMB is allowed to fluctuate inside a small band centered around a dollar parity. Inside the band the exchange rate will fluctuate responding to supply and demand in the market and to intervention by the People's Bank of China (PBC). The crucial element

\footnotetext{
${ }^{7}$ The theoretical reasoning explaining Chinese debt dynamics is omitted in the present paper but can be found in the version of the paper published on the authors' web pages: http://econ-www.mit.edu and http:/ /www.igier.uni-bocconi.it.

(C)2006 The Authors

Journal compilation (C2006 Institute of World Economics and Politics, Chinese Academy of Social Sciences
} 
of the new regime is obviously the determination of the central parity.

The Central Bank says that it will announce the closing price of the US dollar in the interbank foreign exchange market after the closing of the market on each working day, and will make it the central parity for the trading against the RMB on the following working day. The closing parity, and, therefore, the central parity the following day, will depend on intervention. In principle, with excess demand for RMB and limited intervention, the currency could hit the top of the band each day. The regime would turn into a crawling peg with a 6 percent monthly revaluation. The observation that the PBC has not ruled out such an outcome gives an indication of what the final revaluation might be. This possibility by itself will put upward pressure on the RMB. The result is that the accumulation of reserves, required simply to avoid a revaluation in excess of 0.3 percent per day, might be even larger than in the fixed exchange rate regime (the data on reserve accumulation since July suggest that this has not happened so far). Eventually China might find it easier to allow the RMB to float.

How large might the appreciation be in the end? In 2004 the PBC accumulated US\$200bn in foreign exchange reserves. Half was related to trade and foreign direct investment (FDI): US $\$ 50 \mathrm{bn}$ from the trade surplus and US\$50bn from FDI. The remaining US\$100bn was largely speculative, in anticipation of revaluation: portfolio investment, remittances and repatriated profits.

Under floating, these one-way speculative flows would disappear. Under pure floating, that is with no further accumulation of reserves on the part of the PBC, the revaluation would need to cancel the sum of the trade surplus and the FDI flows. How large this might be is impossible to tell. The elasticity of exports to the exchange rate is likely to be low; but nobody really knows. The most relevant margin might be the loss of competitiveness visà-vis countries behind China, Pakistan, Egypt, and the Maghreb in particular. In any case a very large appreciation could not be ruled out. Using US elasticities, which are likely to be larger than those relevant for China, an appreciation of at least 30 percent would be likely. ${ }^{8}$ The relative price difference among Chinese goods and similar goods produced by some of China's main competitors, for instance other South-East Asian countries or the Maghreb, is $20-30$ percent.

To relieve the pressure on the RMB, the PBC could do two things. First, it could remove capital controls asymmetrically; that is, remove them on capital outflows but not on

\footnotetext{
${ }^{8}$ Typical estimates for the USA imply that an appreciation of 10 percent decreases exports by 9 percent and increases import volumes by 8 percent. Using these numbers for China, assuming export and import ratios to GDP of 25 percent, and the need for a change of 5 percent in the ratio of the current account to GDP implies an appreciation of approximately 30 percent.
} 
inflows. The bank could let Chinese investors acquire foreign assets, or announce a path for the gradual removal of capital outflows; this does not need to happen right away for it to have an effect on the exchange rate today. The extreme RMB exposure of Chinese investors suggests that portfolio diversification might significantly add to the supply of $\mathrm{RMB}$, limiting the appreciation.

Would the gradual removal of capital controls create problems in the banking system? The concern is that portfolio diversification would reduce deposits at a rate faster than the speed at which banks can liquidate their loan portfolio. This risk is probably limited. The central bank has sterilized the reserve inflow by issuing sterilization bonds, and most of these bonds are held by commercial banks. So, consider the simple case where private Chinese investors diversify by buying all the reserves of the Central Bank and reduce their deposits with commercial banks by the same amount. In this case, the effects on the balance sheet of commercial banks would cancel. On the asset side, the banks would lose the equivalent of US\$700 bn in sterilization bonds, and the same would happen on the liability side, through the fall in deposits.

What if Chinese private investors wanted to acquire more dollar assets than the dollar assets currently held by the PBC? A simple computation is useful here. The reserves of the $\mathrm{PBC}$ are roughly equal to 40 percent of Chinese GDP. Financial wealth, measured by broad money, is equal to 180 percent of GDP. If Chinese investors were to hold 25 percent of their wealth in the form of US assets, they would want to accumulate US assets equal to 45 percent (180 percent times 25 percent) of GDP, so more than the PBC currently holds. In this case, a credit squeeze would become a possibility. Even more serious would be the possibility that banks might be unable to recover loans fast enough because the moment they attempted to do so, they would discover that many of these loans can no longer be recovered. Some banks might become bankrupt. This suggests that liberalization of capital outflows, although necessary to relieve the pressure on the RMB, should be gradual. This could, for example, be done along the lines suggested by Prasad and Rajan (2005); namely, through the creation of a closed-end mutual fund, available to domestic investors, and invested in foreign assets. Wider liberalization could then take place after the improvement of the banking system, in particular after the creation of a "credit culture" and better screening of loans by banks.

The second way in which the PBC can limit the appreciation, at least for some time, is by continuing to accumulate reserves. There is potentially a good argument for doing so: by limiting the appreciation, reserve accumulation allows for higher exports, and potentially higher learning by doing and productivity growth. The capital loss on the accumulated reserves when the appreciation eventually takes place could in principle be smaller than the 
output gain from the higher productivity growth; in that case, it makes sense to accumulate further reserves, at least for some time. Whether this condition is satisfied is obviously very difficult to assess. ${ }^{9}$

Turn now to the macroeconomic effects of an appreciation. They are likely to be twofold. First, to the extent that the appreciation worsens China's competitiveness, exports will decrease, and so will the export sector. In the absence of other measures, the fall in exports is unlikely to be accompanied by an increase in demand in the rest of the economy. The positive terms-of-trade effect of the revaluation (an argument used by the PBC in explaining the reasons for the new exchange rate regime) is likely to be limited. To maintain internal balance, the revaluation must be accompanied by an increase in internal demand.

This takes us back to our earlier discussion of saving. The reduction in risk and the implied decrease in saving might be justified not only on welfare grounds, as discussed earlier. They might also be justified as the right policy to accompany the revaluation.

Second, the appreciation is likely to worsen inequalities between regions, and between skilled and unskilled workers. The reason is that China is a price-taker in world agricultural markets. Given a price in dollars, the appreciation will lower the domestic currency price of agricultural products and, therefore, real income in the countryside. ${ }^{10}$ Furthermore, through migration, it will put downward pressure on the wage of unskilled workers in the industrial sector: the skilled-unskilled differential will also widen. The fall in local food prices induced by the appreciation is a transfer from farmers to urban (and rural) consumers. With equal propensities to consume, there will be no effect of the transfer on aggregate demand. However, propensities to consume might be different. If it is higher in the countryside than in the cities, the fall in rural incomes (with an official population count of 800 million in the countryside) will have an independent depressing effect on domestic demand. This reinforces the first argument above.

Even if there is no effect on aggregate demand from the transfer, increasing inequality is undesirable. This takes us back to our discussion of inequalities earlier. The provision of health care or measures aimed especially at rural provinces, such as the elimination of the poll tax, are justified on welfare grounds, whether or not the RMB is revalued. However, they are even more justified in the face of the revaluation induced change in income

\footnotetext{
${ }^{9}$ According to our simple computation, although some reserve accumulation might be justified, the current rate of accumulation is almost certainly too high.

${ }^{10}$ Two examples from the past: in the inter-war period, when Italy returned to the gold standard revaluing the Lira by 50 percent, the result was a deep recession in the countryside. Agricultural prices fell notwithstanding the attempt to isolate the Italian market through a tax on imported wheat. Similarly, as Keynes vividly describes in his Essays on Persuasion, the return to gold in the UK destroyed the coal industry.
} 
distribution.

Are there other ways to reduce manufacturing exports while avoiding the adverse effect of an appreciation on farm income and inequality? In principle, yes, and these should be explored. For example, the introduction of a pollution tax and a decrease in subsidies to FDI would limit the extent of currency appreciation needed to reduce the incentive to invest in the export sector. (Some have suggested the use of an export tax, which would potentially limit the fall in agricultural prices. We are skeptical that such an export tax can be implemented without major distortions in China today.)

\section{A Tentative Package}

Our discussion suggests the following package.

Eliminate some of the imperfections behind the high precautionary saving rate. Measures here range from the design of a more robust retirement system, to the provision of health insurance, to the development of private insurance, to better property rights leading banks to lend less on collateral and more on projects.

These measures will increase welfare directly, but also decrease saving in the process.

Let the RMB appreciate, so as to reallocate activity away from the export sector. The announced gradual removal of controls on capital outflows and of tax breaks on FDI would limit the upward pressure on the RMB. Eventually, China should consider replacing the exchange rate rule announced in July with a simple clean float, because the new rule is more likely than not to induce an acceleration of capital inflows.

Other tools can help here. A pollution tax, for instance, would reduce the incentive to invest in the export sector without negatively affecting rural incomes. The larger the pollution tax, the smaller the required appreciation for a given reallocation, and the smaller the effect on rural/urban inequality.

Increase the public provision of health and other public services. Do so in such a way that these are especially targeted to the countryside, all the more so since the appreciation will redistribute income from rural to urban areas. Preventing funds transferred from the center to the rural provinces disappearing through corruption is obviously a first order priority.

The three ingredients, however, need to be carefully balanced:

Too much reduction in individual risk would lead to a large drop in saving. To avoid overheating this would require a large appreciation.

Too large an appreciation would increase inequalities: regional (price of agricultural goods) and skill (the implied wage in export sector). It would also slow down the process of 
learning-by-doing in the export sector, reducing TFP growth.

So, how is it ensured that the transition does not lead to a recession, or into overheating, or into too sharp a reduction in the role of exports? The right instrument is probably fiscal policy, in particular the degree of tax versus debt financing of the new health-care expenditure. Given the current growth and interest rate, debt dynamics allow for potentially large primary deficits, at little cost in terms of the ultimate burden of debt.

Could monetary policy help as well? In principle, with capital controls, an increase in interest rates would help slow down domestic demand if needed. However, capital controls have large leakages and might not prevent an upward pressure on the exchange rate.

If successful, such a strategy is likely to reduce the (measured) growth rate of China. This is because productivity growth in services (at least measured productivity growth) is lower than in manufacturing. However, lower growth would not mean lower welfare. Think of the extreme case of a country fully specialized in high-tech manufacturing, but with no health care. The growth rate would be even higher than it is today; welfare would, nevertheless, be quite low. Lower output growth does not imply lower employment growth. If productivity growth is lower by $\mathrm{x}$ percent, then output growth lower by $\mathrm{x}$ percent is compatible with the same employment growth rate as before. The notion of a given "employment elasticity of growth", invariant to the composition of output, used in some analyses of Chinese growth and discussions of the appropriate growth rate for China, makes no sense and should be discarded.

\section{References}

Bi an, Yanjie, Weimin Zhang and Yongli Liu, 2004, "Social stratification, home ownership and quality of living: Evidence from the 2000 Census," Paper presented at the International Conference on China's 2000 Population and Housing Census, April, Beijing, China.

Blanchard, Olivier and Francesco Giavazzi, 2004, "Improving the SGP through a proper accounting of public investment," in Reformer le Pacte de Stabilite et de Croissance, Paris: Conseil d' Analyse Economique, Paris.

Brun, Jean-François, Jean-Louis Combes and Mary-Françoise Renard, 2002, “Are there spillover effects between coastal and non coastal regions in China?" Mimeo. Clermont Ferrand: Université Blaise Pascal.

Chamon, Marc and Eswar Prasad, 2005, "Determinants of household saving in China." Mimeo. Research Department, Washington DC: International Monetary Fund.

Diamond, Peter, 2004, "Report on social security reform in China," China Economic Research and Advisory Program, Singapore: University of Singapore.

Gao, Jun, Juncheng Qian, Bo Eriksson and Erik Blas, 2002, "Health equity in transition from planned to market economy in China," Health Policy Planning, Vol. 17, (Suppl 1), pp. 20-29. 
Hausmann, Ricardo, 2005, “China's growth miracle in perspective,” Mimeo. Kennedy School of Government, Harvard University, Cambridge, USA.

Hu, Albert, Gary Jefferson and Jinchang Qian, 2003, "R\&D and technology transfer: Firm-level evidence from Chinese industry," William Davidson Institute Working Paper No. 582.

Hu, Angang and Jinghai Zheng, 2004, "Why China's TFP has dropped," mimeo, Center for China Studies, School of Public Policy and Management, Tsinghua University, Beijing.

Jones, Derek, Cheng Li and Ann Owen, 2003, "Growth and regional inequality in China during the reform era,” William Davidson Institute Working Paper No. 561, University of Michigan, Ann Arbor, MI.

Kanbur, Ravi and Xiaobo Zhang, 2003, "Spatial inequality in education and health care in China," International Food Policy Research Institute, Washington, DC.

Kuijs, Louis, 2005, "Investment and saving in China," World Bank China Office Research Working Paper No. 1, Beijing: World Bank China Office.

Modigliani, Franco and Shi Larry Cao, 2004, "The Chinese savings puzzle and the life cycle analysis," Journal of Economic Literature, Vol. 42, No. 1, pp.145-70.

National Bureau of Statistics of China, 2004, China Statistical Yearbook, Beijing: China Statistical Press.

National Bureau of Statistics of China, 2000, Comprehensive Statistical Data and Materials on 50 Years of New China, Beijing: China Statistical Press.

Pradhan, Menno and Adam Wagstaff, 2005, "Health insurance impacts on health and nonmedical consumption in a developing country," World Bank Policy Research Working Paper No. 3563, Washington DC: The World Bank.

Prasad, Eswar and Raghu Rajan, 2005, "Controlled capital account liberalization: A proposal," International Monetary Fund Policy Discussion Paper, Washington DC: International Monetary Fund.

Qu, Hongbin, 2005, "China's economic insight. Reducing the saving glut,” London: HSBC.

Wang, Mengkui, 2005, "Important Issues concerning China's Medium and Long Term Development (2006-20)," (Zhongguo zhongchangqi fazhan de zhongyao wenti), Beijing: China Development Press.

World Bank, 2004, World Development Indicators 2004, Washington DC: The World Bank.

World Bank, 2001, Vietnam-Growing Healthy: A Review of Vietnam's Health Sector, Hanoi: The World Bank.

$\mathrm{Zu}$, Nong, 2002, "The impacts of income gaps on migration decisions in China," China Economic Review, Vol. 13, Nos. 2-3, pp. 213-30. 